\title{
El pago indebido en el Código Civil peruano (primera parte)
}

\section{Luciano Barchi Velaochaga}

\section{El pago indebido como fuente heterónoma de relaciones obli- gatorias}

El artículo 1267 del Código Civil peruano de $1984^{1}$ (en adelante, CC) se refiere a las atribuciones patrimoniales sin causa por error del solvens; es decir, al "pago indebido": "Artículo 1267.- El que por error de hecho o de derecho entrega a otro algún bien o cantidad en pago, puede exigir la restitución de quien la recibió".

Como puede apreciarse, dicho artículo contiene: i) un supuesto de hecho:" "el que por error de hecho o de derecho entrega a otro algún

1 En lo sucesivo, cuando nos referimos a CC deberá entenderse Código Civil peruano de 1984.

2 De acuerdo con Marcial Rubio, "el supuesto es la hipótesis que formula el autor de la norma jurídica para que, de verificarse u ocurrir en la realidad, se desencadene lógico-jurídicamente la necesidad de la consecuencia". RUBIO CORREA, Marcial. El sistema jurídico. Introducción al derecho. Lima: Fondo Editorial de la Pontificia Universidad Católica del Perú, 2004, p. 97. 
bien o cantidad en pago", y ii) una consecuencia: ${ }^{3}$ la constitución de una relación obligatoria donde quien recibe "indebidamente" (accipiens) ${ }^{4}$ algún bien o cantidad, queda obligado a su restitución frente a quien se lo entrega por error (solvens).

De aquí puede afirmarse que el pago indebido (supuesto de hecho) constituye una fuente heterónoma de relaciones obligatorias (consecuencia). Como indica Luis Díez-Picazo, "en todos aquellos casos en que la relación obligatoria no nace de un negocio jurídico, puede hablarse de una constitución forzosa o heterónoma de la relación. La relación se crea por un poder que es independiente de la voluntad de los sujetos". ${ }^{5}$ Ese poder es la soberanía del Estado, creando relaciones jurídicas entre particulares; por ello se dice que es una constitución heterónoma de relaciones obligatorias. En concreto, se trata de un supuesto legalmente tipificado: ${ }^{6}$ basta que se realice el supuesto de hecho contemplado en la norma (un desplazamiento patrimonial sin causa) para que se constituya la relación obligatoria, independientemente de la voluntad de los sujetos de derecho. Por esta razón, la mayoría de las legislaciones ubican al pago indebido, adecuadamente, en el libro de fuentes de las obligaciones y no en la parte relativa al "pago", como lo hace nuestro CC.

3 Según Rubio Correa, “La consecuencia es el efecto que el autor de la norma jurídica le atribuye lógico-jurídicamente a la verificación del supuesto en la realidad". RUBIO CORREA, Marcial. Op. cit., p. 101.

4 Llamamos accipiens al sujeto que recibe el "pago indebido", y solvens a quien lo efectúa.

5 DÍEZ-PICAZO, Luis. Fundamentos del derecho civil patrimonial. Volumen I. 5. a edición. Madrid: Civitas, 1996, p. 154. Ver, también, DÍEZ-PICAZO, Luis. “Los llamados contratos forzosos", en CÁRDENAS QUIRÓS, Carlos. Materiales de lectura del curso Derecho Civil Patrimonial II. Lima: Maestría en Derecho Empresarial de la Universidad de Lima.

6 Ibíd., p. 154.

7 Tradicionalmente se ha considerado el "pago indebido" como una especie de "cuasicontrato". Para Ballarín Hernández, el pago indebido es un cuasicontrato. Ver, al respecto, BALLARÍN HERNÁNDEZ, Rafael. El cobro de lo indebido. Perfiles institucionales y eficacia traslativa. Madrid: Tecnos, 1985, p. 43 y ss. Respecto a la crítica de los "cuasicontratos", ver DÍEZ-PICAZO, Luis. Fundamentos del derecho

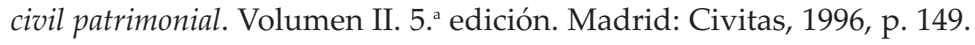




\section{El pago indebido como desplazamiento patrimonial sin causa}

La "entrega a otro [de] algún bien o cantidad" constituye una atribución o desplazamiento patrimonial.

Una atribución o desplazamiento patrimonial consiste en una ventaja o beneficio de carácter patrimonial proporcionado a otra persona; implica, por consiguiente, la alteración en la esfera patrimonial de un sujeto. Así, la entrega de un bien a (o la realización de un servicio a favor de) un sujeto de derecho constituye una atribución o desplazamiento patrimonial.

Si bien "atribución" y "desplazamiento" pueden ser entendidos como sinónimos, en estricto, el término desplazamiento es más concreto que el término atribución, ya que requiere que la citada ventaja o beneficio se materialice en un bien (o dinero), dejando así al margen toda atribución patrimonial que implique un hacer o un no hacer.

Como dice Díez-Picazo:

Todo desplazamiento patrimonial, todo enriquecimiento y, en general, toda atribución, para ser lícitos, deben fundarse en aquellas causas o razones de ser que el ordenamiento jurídico considera como justas. Cuando una atribución patrimonial no está fundada en una justa causa, el beneficiario de la atribución debe restituir al atribuyente el valor del enriquecimiento y, correlativamente, surge una acción o una pretensión, en favor de este último, para obtener o reclamar dicha restitución. ${ }^{8}$

Para que un desplazamiento patrimonial pueda ser calificado de pago es menester que: 1) encuentre su fundamento y su razón de ser en una previa relación obligatoria (causa o título) que a través de dicha atribución se cumple; y 2) concurran una serie de requisitos que se refieren a los sujetos, al objeto y a las circunstancias de tiempo y de lugar (requisitos de regularidad del pago). ${ }^{9}$

8 DÍEZ-PICAZO, Luis. Fundamentos del derecho civil patrimonial. Volumen I. Op. cit., pp. 89-90.

9 El despliegue de la plena eficacia, solutoria y satisfactiva, del acto de pago, exige 
Por lo señalado, para que un desplazamiento patrimonial sea considerado pago debe ser debido; es decir, debe tener una causa, la cual es, comúnmente, una relación obligatoria. Así por ejemplo, si Primus entrega a Secundus S/.1.000, realiza un desplazamiento patrimonial a favor de este último; sin embargo, para que dicho desplazamiento sea calificado como pago debe preexistir una relación obligatoria entre Primus y Secundus, la cual constituiría la causa o título del desplazamiento patrimonial.

El pago se califica precisamente como hecho debido en cuanto constituye la actuación de la relación obligatoria y, por tanto, actuación de la posición deudora. La relación obligatoria es entonces el título jurídico del pago. Si para que un desplazamiento patrimonial sea pago debe existir una causa o título, entonces un pago siempre es debido; hablar de pago indebido resulta siendo contradictorio. Así, quizá resulte más adecuado referirse a atribuciones o desplazamientos patrimoniales sin causa. ${ }^{10}$

Los desplazamientos patrimoniales requieren, como se ha visto, de una causa que los justifique jurídicamente. De acuerdo con Trimarchi, ${ }^{11}$ los desplazamientos patrimoniales injustificados pueden verificarse como consecuencia de:

la concurrencia de una serie de requisitos que se refieren a los sujetos, al objeto y a las circunstancias de tiempo y de lugar.

1) Desde el punto de vista de los sujetos, la regularidad del pago presupone la legitimación de la persona que lleva a cabo el pago (solvens) y de la persona que lo recibe (accipiens).

2) Desde el punto de vista del objeto, son requisitos del pago: la identidad, la integridad y la indivisibilidad.

3) Desde el punto de vista de las circunstancias de tiempo y de lugar, el pago exige que el tiempo y el lugar en que se realice sean exactos o por lo menos adecuados.

10 El Código Civil español habla de "cobro de lo indebido". Cárdenas Quirós habla de "desplazamiento patrimonial indebido": CÁRDENAS QUIRÓS, Carlos. "Hacia la reforma del libro VI del Código Civil". Thémis 30, p. 147.

11 TRIMARCHI, Pietro. Istituzioni di diritto privato. Quindicesima edizione. Milano: Giuffrè, 2003, p. 332. 
1) Apropiaciones ilícitas, o bien por el empleo de violencia, amenazas o engaños. En este caso, las consecuencias se eliminan, en lo posible, mediante el mecanismo de la responsabilidad civil.

2) Hechos que no son ilícitos y no son fuente de responsabilidad por daños. Así por ejemplo, puede tratarse:

2.1) De hechos del mismo empobrecido, quien por error entrega a otro sujeto un bien no debido;

2.2) De un hecho de la naturaleza, como la avulsión (artículo 940 del $\mathrm{CC}) ; \mathrm{o}$

2.3) De un hecho del enriquecido sin ser fuente de responsabilidad civil por los daños; así por ejemplo, el consumo de buena fe de un bien ajeno.

Cuando los desplazamientos patrimoniales se producen por hechos que no son ilícitos y no son fuente de responsabilidad por daños, ${ }^{12}$ el derecho no impone al enriquecido de buena fe - como señala el autor italiano ${ }^{13}-$ el resarcimiento del daño, pero sí la obligación de pagar al empobrecido una indemnización dentro de los límites de su enriqueci-

12 Como bien lo resalta Trimarchi, no todo acto dañoso es prohibido. En la vida en sociedad es común causar daño a otros sujetos lícitamente. El desarrollo de actividades provechosas implica algún riesgo de daños a terceros (externalidades, para los economistas; daños, para los abogados). No todas las externalidades deben ser internalizadas a través de la responsabilidad civil; de lo contrario, la sociedad se paralizaría por el impacto que tendría sobre cada persona la existencia de sanciones resarcitorias por todas las consecuencias dañosas, nimias o relevantes, inmediatas o remotas, que involucra toda actividad humana. El éxito empresarial, por ejemplo, se manifiesta restándoles clientes a los competidores, pero ello no constituye un hecho injusto: la competencia no está prohibida; al contrario, es reconocida constitucionalmente (artículo 61), pues es útil para la sociedad. Otras veces, el hecho dañoso es prohibido (hecho ilícito) y, una vez cometido, da lugar a responsabilidad por daños. Ver, al respecto, TRIMARCHI, Pietro. Istituzioni di diritto privato. Op. cit., p. 107.

13 TRIMARCHI, Pietro. Istituzioni di diritto privato. Op. cit., p. 332. 
miento. Como señala Gallo: "La responsabilidad civil busca de remediar los daños derivados de la comisión del ilícito; la acción de enriquecimiento tiene, en cambio, como punto de referencia el provecho obtenido mediante un hecho injusto". ${ }^{14}$

$\mathrm{Si}$, por ejemplo - usando el ejemplo de Trimarchi-, Primus ha utilizado el carbón de Secundus, este sufre un daño igual al valor del carbón; el enriquecimiento de Primus, en cambio, es igual al precio no pagado por igual cantidad de carbón. Si Primus no ha actuado de mala fe, no es responsable por el daño, pero está obligado según el principio del enriquecimiento sin causa; por tanto, debe pagarle a Secundus una suma de dinero igual al precio del carbón ahorrado.

El principio general está recogido en el artículo 1954 del CC: "Aquel que se enriquece indebidamente a expensas de otro está obligado a indemnizarlo". Este principio se reafirma en otras disposiciones del CC, particularmente, en las normas del pago indebido. Como señala Bianca, "el pago indebido precisamente ha quedado como una particular hipótesis de enriquecimiento injustificado, caracterizada por la ejecución de una prestación 'no debida' y del derecho de repetición respecto el accipiens". ${ }^{15}$

El ordenamiento jurídico no impone al accipiens, que recibe el pago indebido, el resarcimiento del daño, sino que lo obliga a restituir al consumidor aquello en lo que se hubiese enriquecido. En tal sentido, el enriquecimiento sin causa no debe ser entendido como un tema de "responsabilidad civil" ${ }^{16}$

14 GALLO, Paolo. "Arricchimento senza causa. Artt. 2041-2042", en Il Codice Civile. Commentario. Fondata da Piero Schlesinger, diretto da Francesco D. Busnelli. Milano: Giuffrè, 2003, p. 50.

15 BIANCA, Massimo. Diritto civile. 5. La responsabilità. Milano: Giuffrè, 1994, p. 792. En este mismo sentido, TRIMARCHI, Pietro. Istituzioni di diritto privato. Op. cit., p. 354; DÍEZ-PICAZO, Luis. Fundamentos del derecho civil patrimonial. Volumen II. Op. cit., p. 516.

16 Díez-Picazo considera que no son admisibles ni la posición que fusiona el enriquecimiento dentro del resarcimiento de daños, ni la que establece una total y absoluta separación. En las hipótesis de enriquecimiento injustificado puede existir un daño. DÍEZ-PICAZO, Luis. Fundamentos del derecho civil patrimonial. Volumen I. Op. cit., p. 96. 


\section{El pago indebido como desplazamiento patrimonial sin causa por error del solvens}

Las normas relativas al pago indebido resultan de aplicación cuando la atribución patrimonial sin causa la realiza el propio empobrecido por error (por error de hecho o de derecho, dice la norma). Adviértase también que el artículo 1267 del CC se refiere en concreto a "desplazamientos patrimoniales", pues la atribución se materializa en un bien o en dinero ("entrega a otro algún bien o cantidad de pago"), y eso se hace patente en el articulado.

De acuerdo con el artículo 1267, para que se configure el pago indebido, el desplazamiento patrimonial sin causa debe ser realizado por error del solvens; si se realiza un desplazamiento sin causa conscientemente (sin error), no estaríamos dentro de un supuesto de pago indebido. ${ }^{17}$ Así por ejemplo, si Primus decide pagar a Secundus una deuda de Tertus, no se trata de un pago indebido, sino de un pago por tercero.

En el Código Civil italiano, el pago indebido puede ser objetivo o subjetivo. Será objetivo, conforme al artículo 2033, cuando el solvens realiza el desplazamiento patrimonial respecto a un título inexistente o ineficaz; mientras que será subjetivo, conforme al artículo 2036, cuando el solvens paga una deuda ajena en la errónea creencia de ser él el deudor.

Como se ha señalado, el CC requiere siempre la existencia del error de parte del solvens; por tanto, podríamos decir que en nuestro ordenamiento civil el pago indebido es siempre subjetivo. No obstante, como veremos al tratar el tema de la prueba, no se requiere probar el error cuando se realiza una atribución patrimonial que nunca se debió o que ya estaba pagada.

17 Según Díez-Picazo, “en los casos en que el pago de lo indebido ha sido realizado conscientemente, de acuerdo con esta tradición, no se le puede suponer otra intención que la de realizar una liberalidad". Sin embargo, más adelante el autor español reconoce la posibilidad de que el solvens realice la atribución patrimonial sin error y sin pretender llevar a cabo una liberalidad, como por ejemplo, evitar los perjuicios que de no hacer el pago se seguirían: DÍEZ-PICAZO, Luis. Fundamentos del derecho civil patrimonial. Volumen II. Op. cit., p. 517. En este caso, procede la acción general de enriquecimiento sin causa. 
Error de hecho o de derecho

De acuerdo con el artículo 1267 del CC, el error puede ser de hecho (error facti) o de derecho (error iuris).

\section{Error de derecho}

En el derecho inglés, respecto al error iuris se aplicó, en un principio, la mistake of law rule: el que pagaba una suma de dinero a causa del errado convencimiento de estar obligado por la ley, no podía obtener la restitución. Así, el desplazamiento patrimonial injustificado fue considerado estable en virtud del principio ignorantia ius non excusat. ${ }^{18}$

Si bien de acuerdo con el principio ignorantia ius non excusat, nadie puede alegar ignorancia de la ley, ${ }^{19}$ el mismo no debe ser transportado al tema del pago indebido. La mistake of law rule es incompatible con un sistema que funda el remedio restitutorio en la ausencia de justificación del desplazamiento patrimonial. ${ }^{20}$ En efecto, como se ha señalado, el pago indebido es una particular hipótesis de enriquecimiento indebido. Así, el remedio restitutorio se justifica por la falta de causa del desplazamiento patrimonial.

\section{Error de hecho}

El error de hecho es aquel que lleva al empobrecido (solvens) a realizar un desplazamiento patrimonial mediando una falsa representación mental, o en ausencia de noción acerca de algún elemento esencial de la relación obligatoria.

El error de hecho puede distinguirse en absoluto y relativo.

Error absoluto

En el desplazamiento patrimonial por error absoluto, el solvens realiza el

$18 \mathrm{Al}$ respecto, ver D'ANGELO, Antonino. L'errrore senza rimedio. Milano: Giuffrè, 2006.

19 Ver, al respecto, CORRAL TALCIANI, Hernán Felipe. De la ignorancia de la ley. El principio de su inexcusabilidad. Santiago: Editorial Jurídica de Chile, 1987.

20 En este sentido, D’ ANGELO, Antonino. Op. cit., p. 23. 
desplazamiento con la errónea creencia de la existencia del título, sea porque nunca existió, sea porque ya se extinguió.

La ausencia del título puede ser desde el origen o puede ser sobreviniente. Siguiendo a Bianca, se pueden distinguir los siguientes casos: ${ }^{21}$

1) Por inexistencia de la relación obligatoria;

2) Por extinción previa de la relación obligatoria;

3) Por falta de legitimación del accipiens; y

4) Por nulidad, anulabilidad, resolución y rescisión del título negocial (condictio ob causam finitam).

En todos estos casos, de acuerdo con el CC, el solvens incurre en error sobre la existencia del título.

\section{1) Por inexistencia de la relación obligatoria}

Se trata de un "desplazamiento patrimonial no debido". En este supuesto incluimos el caso del sujeto no deudor que paga una deuda ajena al acreedor; es decir, el pago indebido ex latere solventis.

Cuando este desplazamiento patrimonial se hace conscientemente, estamos frente a un "pago por el tercero". ${ }^{22}$ En el caso del tercero que paga una deuda ajena, si hay una declaración de pagar una deuda ajena, estamos entonces frente a un "pago por tercero", y en este caso sí hay un desplazamiento patrimonial con causa. Como señala Levi, para que se dé un cumplimiento por tercero, "debe darse la voluntad del solvens

${ }^{21}$ Bianca no menciona la rescisión, pero nosotros la incluimos: BIANCA, Massimo. Diritto civile. 5. La responsabilità. Op. cit., p. 795. Trimarchi sí menciona la rescisión: TRIMARCHI, Pietro. Istituzioni di diritto privato. Op. cit., p. 333.

22 El artículo 1222 del CC establece quiénes están legitimados para efectuar el pago; en tal sentido, señala: "Puede hacer el pago cualquier persona, tenga o no interés en el cumplimiento de la obligación, sea con el asentimiento del deudor o sin él, salvo que el pacto o su naturaleza lo impidan...". 
de cumplir una atribución patrimonial a favor del acreedor, atribución que debe ser referida a una cierta relación obligatoria". Y añade: "no es suficiente que el tercero realice la objetiva actuación del derecho del acreedor".23

El pago por tercero determina en el deudor un enriquecimiento que consiste en la liberación de la deuda frente al acreedor originario; por eso, el tercero tiene derecho a "reclamar" el reembolso, vía enriquecimiento sin causa, al deudor (enriquecido). El derecho de reembolso es aquel que faculta a quien pagó por otro, a recobrar lo pagado. ${ }^{24}$

En el caso del pago indebido ex latere solventis (indebitum ex persona a parte debitoris), el solvens realiza el desplazamiento patrimonial por error, creyéndose deudor, sin la intención de pagar una deuda ajena. Al recibir la atribución patrimonial, el accipiens no necesariamente actuará de mala fe, pues es posible que, conforme al artículo 1222 del CC, pueda pensar que la intención del solvens es pagar la deuda ajena.

En Italia, partiendo del pago indebido objetivo, Turco señala:

Ha sido exactamente observado a propósito que, de un examen sistemático de la disciplina del pago indebido dictada por nuestro código civil, se deduce claramente que "el error no es una condición general de la repetibilidad del pago no debido"; debiéndose al contrario afirmarse que "la consciencia" de haber ejecutado tal pago "o bien la simple negligencia de ejecutarlo (...) pueden hacer inexigible la pretensión del actor, no obstante la existencia de los presupuestos legales que de por sí serían suficientes para el nacimiento de la obligación restitutoria. ${ }^{25}$

23 LEVI, Giulio. Il pagamento dell'indebito. Milano: Giuffrè, 1989, p. 129.

24 Para recobrar lo pagado se cuenta con dos vías: 1) la "acción" de reembolso; 2) la "acción" in rem verso; y 3) la subrogación. Ver, respecto al derecho de reembolso, TUR FAUNDEZ, María Nélida. El derecho de reembolso. Valencia: Editorial General de Derecho, 1996.

25 TURCO, Claudio. "L'adempimento del terzo. Art. 1180", en Il Codice Civile. Commentario. Diretto da Piero Schlesinger. Milano: Giuffrè, 2002, p. 69. 


\section{2) Por extinción previa de la relación obligatoria}

Un ejemplo es el del solvens que realiza el desplazamiento patrimonial respecto de una relación obligatoria que ya no existe, pues ha sido pagada previamente.

De los Mozos se refiere al pago de una deuda extinguida previamente por compensación. Al respecto, señala: "Como en nuestro Derecho la compensación se produce automáticamente hasta el límite de la cantidad concurrente, aunque no tengan conocimiento de ello los acreedores y deudores (art. 1202 Cc.), es perfectamente posible que se vuelva a producir el pago de una deuda total o parcialmente extinguida, en cuyo caso procede la repetición" ${ }^{26}$

La compensación legal es la compensación que tiene lugar cuando entre dos personas existen relaciones obligatorias recíprocas que cumplen con los presupuestos establecidos por la ley; en nuestro caso, los del artículo 1288 del CC: "Por la compensación se extinguen las obligaciones recíprocas, líquidas, exigibles y de prestaciones fungibles y homogéneas, hasta donde respectivamente alcancen, desde que hayan sido opuestas la una a la otra. La compensación no opera cuando el acreedor y el deudor la excluyen de común acuerdo".

Para ciertas legislaciones, como la española, ${ }^{27}$ la compensación legal opera de pleno derecho en cuanto se dan los presupuestos legales establecidos en la ley. Para otras legislaciones, la compensación requiere que se den dichos presupuestos, pero corresponde a los sujetos invocarla. Una vez invocada, la compensación puede retrotraerse al momento en que se dieron los presupuestos establecidos en la ley.

De acuerdo con el artículo 1288 del CC, los efectos de la compensación se producen "desde que hayan sido opuestas la una a la otra". Osterling y Cárdenas, al comentar dicho artículo, dicen que "la compensación solo opera desde que se opone una obligación a la otra, sin

26 DE LOS MOZOS, José Luis. "Pago o cobro de lo indebido". Revista de Derecho Privado, p. 659.

27 El artículo 1202 del Código Civil español establece: “El efecto de la compensación es extinguir una y otra deuda en la cantidad concurrente, aunque no tengan conocimiento de ella los acreedores y deudores". 
otorgarle efectos retroactivos a la fecha de coexistencia de ambos créditos". ${ }^{28}$

En tal sentido, para nuestro CC sólo podría darse pago indebido si, luego de opuesta la compensación por cualquiera de los deudores, uno de ellos realiza el pago. ${ }^{29}$

\section{3) Por falta de legitimación del accipiens ${ }^{30}$}

En el pago indebido ex latere accipientis (indebitum ex persona parte creditoris), el deudor o el legitimado ${ }^{31}$ paga la deuda a quien no se encuentra legitimado para recibir. En otras palabras, quien cumple es verdaderamente deudor, pero cumple a favor de persona distinta del acreedor o del legitimado a recibir el pago. ${ }^{32}$

De acuerdo con el artículo 1224 del CC, el pago al tercero no legiti-

${ }^{28}$ OSTERLING PARODI, Felipe (con la colaboración de Carlos CÁRDENAS QUIRÓS). Las obligaciones. Biblioteca Para leer el Código Civil. Volumen VI. Lima: Fondo Editorial de la Pontificia Universidad Católica del Perú, 1988, p. 207.

29 Salvo, obviamente, que se trate de una compensación parcial y se pague el saldo no compensado.

30 En Italia, el pago indebido ex latere accipientis es un supuesto de pago indebido subjetivo y, por tanto, un caso donde existe relación jurídica, pero no entre las personas que han realizado la atribución patrimonial. No obstante, al respecto, Barbero señala: “La situación, a nuestro juicio, se asimila a la que emana del pago indebido objetivo, por cuanto se puede decir perfectamente que el pago a aquel accipiens no era debido ni por el solvens ni por otra persona: no era debido objetivamente": BARBERO, Domenico. Sistema del derecho civil patrimonial. Tomo IV. Buenos Aires: Ediciones Jurídicas Europa-América, 1967, p. 687. El pago indebido objetivo supone la inexistencia o invalidez de la relación.

31 El artículo 1222 del CC establece quiénes son los legitimados para efectuar el pago.

32 El artículo 1224 del CC establece los legitimados a recibir el pago: "Sólo es válido el pago que se efectúe al acreedor o al designado por el juez, por la ley o por el propio acreedor, salvo que, hecho a persona no autorizada, el acreedor lo ratifique o se aproveche de él". 
mado es ineficaz (el CC habla impropiamente de validez ${ }^{33}$ ) respecto al acreedor. El deudor se mantiene, entonces, obligado a ejecutar la prestación.

El acreedor puede ratificar el pago con efecto liberatorio desde el momento de su ejecución. También puede ratificarlo quien tiene la legitimación de disponer del crédito.

Asimismo, es posible que el acreedor hubiera aprovechado el pago hecho al tercero no legitimado; en tal caso, el deudor queda liberado. El acreedor aprovecha el pago cuando la prestación queda a su disposición. Por ejemplo: el comprador paga el precio al transportista de la mercadería, y este, aun cuando no está legitimado a recibir el pago, lo remite al vendedor. También el acreedor aprovecha el pago cuando obtiene un incremento económico; en los límites de tal incremento, el deudor es liberado. Por ejemplo: el deudor, sin haber estado autorizado, ejecuta el pago en manos de un tercero que es, a su vez, acreedor del acreedor; quien recibe debería remitir la prestación a su destinatario, pero, siendo su acreedor, satisface su derecho por compensación. El acreedor no ha recibido la prestación, pero ha conseguido la utilidad económica de la liberación de su deuda.

El tercero no legitimado que recibe la prestación está obligado a restituirla al deudor, pues se trata de un pago indebido ex latere accipientis. El solvens puede, por tanto, reclamarle al tercero no legitimado la repetición de lo que le ha entregado, salvo que el acreedor hubiera recibido o declarado querer recibir la prestación por parte del tercero.

33 Hablar de validez supone categorizar el pago como un acto jurídico (acto jurídico stricto sensu o negocio jurídico), pues el plano de validez sólo corresponde a los hechos jurídicos en los cuales la voluntad constituye el núcleo del supuesto de hecho. Los hechos jurídicos stricto sensu no pueden ser nulos o anulables. Así por ejemplo, no puede haber un nacimiento nulo (ver, al respecto, MELLO, Marcos Bernardes de. Teoria do fato jurídico. 2. ${ }^{a}$ ediçåo. Såo Paulo: Saraiva, 1986, p. 94 y ss.). Para nosotros, la incapacidad del deudor no excluye su legitimación para cumplir; no obstante, el ordenamiento jurídico activa los mecanismos de protección al incapaz cuando el pago implica un detrimento económico superior a aquel requerido por el exacto cumplimiento. 
Un caso distinto es el pago al acreedor aparente, el cual sí produce el efecto liberatorio conforme a lo dispuesto por el artículo 1225 del CC. ${ }^{34}$ El efecto liberatorio requiere dos presupuestos:

a) La buena fe de quien efectúa el pago respecto a que quien lo recibe sea el legitimado para hacerlo; $y$

b) La apariencia de legitimación de quien recibe.

La apariencia puede referirse a la identidad del legitimado. Por ejemplo: quien recibe, valiéndose de un falso documento, se hace pasar por el acreedor.

La apariencia puede referirse al título de la legitimación. Por ejemplo: el acreedor originario ha cedido el crédito sin que el deudor hubiera tenido conocimiento (legitimación histórica).

4) Por nulidad, anulabilidad, resolución y rescisión del título negocial (condictio ob causam finitam)

En estos casos, la ausencia del título puede ser ab origine (nulidad, anulabilidad ${ }^{35}$ o rescisión $^{36}$ ) o sobreviniente (resolución ${ }^{37}$ ). En el caso de la resolución del contrato, el desplazamiento patrimonial es justificado en el momento en el que se realiza, pero posteriormente deja de serlo por hechos sobrevinientes (incumplimiento, imposibilidad, excesiva onerosidad).

34 Artículo 1225.- Extingue la obligación el pago hecho a persona que está en posesión del derecho de cobrar, aunque después se le quite la posesión o se declare que no la tuvo.

35 De acuerdo con el artículo 222 del CC, "el acto jurídico anulable es nulo desde su celebración, por efecto de la sentencia que lo declare".

36 Conforme al artículo 1372 del CC, "la rescisión se declara judicialmente, pero los efectos de la sentencia se retrotraen al momento de la celebración del contrato".

${ }^{37}$ De acuerdo con el artículo 1372 del CC, “La resolución se invoca judicial o extrajudicialmente. En ambos casos, los efectos de la sentencia se retrotraen al momento en que se produce la causal que la motiva". 
Luis Díez-Picazo, refiriéndose al Código Civil español, señala que "las reglas restitutorias que son consecuencia de la nulidad o de la anulabilidad se encuentran establecidas en sede de contratos" ${ }^{38}$ En el caso peruano, no encontramos en el libro de acto jurídico normas relativas a las reglas restitutorias que son consecuencia de la nulidad o de la anulabilidad. ${ }^{39}$ Sí encontramos en el libro de fuentes de las obligaciones referencias a la restitución en el caso de la resolución. Al respecto, el artículo 1372 del CC señala: "Por razón de la resolución, las partes deben restituirse las prestaciones...". No existe, curiosamente, norma similar respecto a la rescisión.

\section{Error relativo}

En la atribución patrimonial por error relativo existe título, pero el solvens incurre en error sobre los elementos que la ley considera trascendentes. ${ }^{40}$

Los supuestos de atribución patrimonial por error relativo son:

- Pago de cosa cierta distinta.

- Pago en exceso.

- Pago de cosa incierta como cierta.

38 DÍEZ-PICAZO, Luis. Fundamentos del derecho civil patrimonial. Volumen II. Op. cit., p. 517. El artículo 1303 del Código Civil español (de la nulidad de los contratos) señala: "Declarada la nulidad de una obligación, los contratantes debe restituirse recíprocamente las cosas que hubiesen sido materia del contrato, con sus frutos, y el precio con los intereses, salvo lo que se dispone en los artículos siguientes".

39 En Italia, Argiroffi ha señalado, al respecto: "la mayoría de la doctrina considera que la restitución del bien sería disciplinada no en las normas sobre nulidad, etc., sino en las normas sobre repetición de lo indebido y en tema de reivindicación". ARGIROFFI, Carlo. Ripetizione di cosa determinata e acquisto "a domino" della proprietà. Milano: Giuffrè, 1980, p. 9.

40 En este sentido, BUSTAMANTE ALSINA, Jorge. Repetición del pago de lo que no se debe. Buenos Aires: Abeledo-Perrot, 1981, p. 70. 
- Pago de prestación alternativa como cierta.

- Pago de todas las prestaciones alternativas.

- Pago de prestación alternativa, dejando la elección al acreedor cuando - en realidad - ello competía al deudor.

- Caso de la prestación de hacer o de no hacer que el deudor paga prestando un hecho por otro o absteniéndose de un hecho por otro.

- Pago de una obligación parcial como solidaria o indivisible.

- Pago de una obligación sujeta a condición suspensiva, antes de verificarse la condición. ${ }^{41}$

Respecto al pago de cosa cierta distinta, De los Mozos señala: "En este caso se trata también de un pago de lo indebido por no ajustarse a lo dispuesto en el artículo $1157,{ }^{42}$ procediendo la devolución. En cambio, cuando no existe error, a pesar de que haya sido entregada y aceptada una cosa distinta de la debida originariamente, tiene lugar una datio in solutum y el pago está bien hecho". ${ }^{43}$ En efecto, si ambas partes están de acuerdo en que se ejecute una prestación distinta a la debida, se produce una dación en pago. ${ }^{44}$

El pago en exceso constituye un pago indebido. En este caso, existe causa, pero el solvens entrega al accipiens una cantidad mayor a la debida; el error consiste, precisamente, en realizar el desplazamiento patrimonial con la equivocada creencia de que la cantidad debida era mayor. La obligación de restituir se refiere únicamente al exceso, el cual, precisamente, no es debido.

${ }^{41}$ Artículo 173.- (...). El deudor puede repetir lo que hubiese pagado antes del cumplimiento de la condición suspensiva o resolutoria.

42 El artículo 1157 del Código Civil español señala: “No se entenderá pagada una deuda sino cuando completamente se hubiera entregado la cosa o hecho la prestación en que la obligación consistía".

43 DE LOS MOZOS, José Luis. "Pago o cobro de lo indebido". Revista de Derecho Privado. Op. cit., p. 657.

44 Artículo 1265.- El pago queda efectuado cuando el acreedor recibe como cancelación total o parcial una prestación diferente a la que debía cumplirse. 
No obstante, en la Casación 2303-98, publicada el 2 de enero del 2001, se señala lo siguiente:

Que tampoco es de aplicación a este caso el artículo mil doscientos setenta y cuatro del Código Civil que señala el plazo de cinco años para imponer la acción para recuperar lo indebidamente pagado porque se califica así al pago que no se [sic] debió haberse hecho lo que no es asimilable con el supuesto de que la empresa cobre en exceso a los usuarios que es distinto del pago de lo que no se debe o el pago que no corresponde a ninguna obligación legal y se ha hecho por error; en este caso sí había obligación de pago, pero de una suma menor, pudiéndose cobrar el exceso por el usuario.

Como puede apreciarse, la casación citada distingue el pago en exceso del pago indebido. Según ella, el pago en exceso supone la existencia de una "obligación de pago, pero de una suma menor", mientras que el pago indebido es un "pago de lo que no se debe". Hay una evidente contradicción, pues, usando los mismos términos, lo pagado en exceso es un pago de lo que no se debe.

Según Cazeaux y Trigo Represas, “sólo es verdaderamente pago por error el que se cumplimenta entre partes ligadas obligacionalmente, pero con una prestación distinta a la debida o con equivocación en cuanto a ciertas modalidades circunstanciales". ${ }^{45}$ En tal sentido, de acuerdo con los autores argentinos, el pago en exceso (obligación de dar una suma de dinero donde se entrega una mayor cantidad) es un pago indebido.

Para nosotros, como se ha mencionado, el error en el pago indebido puede ser absoluto o relativo. En el error absoluto, el solvens cree que realmente está obligado, sin estarlo; en cambio, en el error relativo, el solvens sí está obligado, pero se equivoca respecto de alguno de los elementos; así por ejemplo: cuando el error recae en la cantidad y se paga más

45 CAZEAUX, Pedro y Félix A. TRIGO REPRESAS. Compendio de derecho de las obligaciones. Tomo II. La Plata: Librería Editora Platense, 1986, p. 516. 
de lo que se debe. El pago en exceso es, sin lugar a dudas, un desplazamiento patrimonial sin causa por error; vale decir, un pago indebido.

De los Mozos se refiere al pago con desconocimiento de que la obligación tenía carácter alternativo: "Cuando la elección corresponde al deudor (artículo $1132 \mathrm{Cc}$ ) ${ }^{46}$ y éste haya pagado ignorando que le correspondía este derecho, podrá pedir la restitución por haberse realizado la prestación con desconocimiento de lo que es esencial en el vínculo jurídico de la obligación alternativa, según el artículo 1131 del Código Civil". ${ }^{47}$

\section{Excusabilidad del error}

El artículo 2036 del Código Civil italiano, que se refiere al "pago indebido subjetivo", exige que el error sea "excusable". De acuerdo con Bianca,

Este requisito de la excusabilidad, recibido de la antigua legislación, introduce a cargo del solvens una carga de ordinaria diligencia en orden a la previa verificación de la propia posición deudora. La falta de absolución de tal carga deviene relevante en la comparación normativa de dos intereses, ambos merecedores de tutela: el del solvens a la restitución de la prestación no debida y el del acreedor a la conservación de la prestación esperada. ${ }^{48}$

En tal sentido, en la legislación italiana, el interés del accipiens prevalece frente al error inexcusable del solvens, prescindiendo de su "conocibilidad".

46 El artículo 1132 del Código Civil español establece: “La elección corresponde al deudor, a menos que expresamente se hubiese concedido al acreedor..." (similarmente al artículo 1162 del CC).

47 DE LOS MOZOS, José Luis. "Pago o cobro de lo indebido". Revista de Derecho Privado. Op. cit., p. 658. El artículo 1131 del Código Civil español establece: “El obligado alternativamente a diversas prestaciones debe cumplir por completo una de éstas..." (similarmente al artículo 1161 del CC).

48 BIANCA, Massimo. Diritto civile. 5. La responsabilità. Op. cit., p. 805. 
En cambio, Díez-Picazo señala al respecto: "por regla general, no es necesaria la excusabilidad del error, como lo es para fundar la impugnación de los contratos por vicios del consentimiento. La acción restitutoria tiene aquí un fundamento objetivo, que es la falta de justificación de la atribución recibida por el accipiens y es independiente de la diligencia o negligencia del solvens". ${ }^{49}$ Del mismo modo, De los Mozos indica: "Tampoco se distingue en el error del solvens que éste sea excusable o inexcusable: ello es plenamente indiferente" ${ }^{\prime 0}$

En la doctrina argentina, si bien no existe unanimidad respecto a si el error debe ser excusable, ${ }^{51}$ la mayoría considera que la excusabilidad no es un requisito exigible. En este sentido, Cazeaux y Trigo Represas señalan:

La exigencia de la excusabilidad del error en materia de nulidad de los actos jurídicos es razonable, pues lo que se persigue es dejar sin efecto un acto que imponía obligaciones al equivocado, y siendo tan graves las consecuencias jurídicas, la ley debió extremar los recaudos y no permitir el reclamo sino cuando hubo razón para errar; por el contrario la acción de repetición no ataca ni destruye el vínculo, y deja al acreedor con todas sus prerrogativas, o sea que no se compromete el interés social que en cambio resiente la nulidad de actos aparentemente puros y válidos. De ahí incluso que se admita la repetición aún en los supuestos de error de "derecho", pese a que éste en general no es invocable. Además, el fundamento de la admisibilidad del error como vicio de la voluntad está en la necesidad de asegurar la pureza del acto voluntario, aunque en miras del supremo interés social el equivocado sólo debe ser merecedor de tal protección no encontrándose en falta

49 DÍEZ-PICAZO, Luis. Fundamentos del derecho civil patrimonial. Volumen II. Op. cit., p. 517.

${ }^{50}$ DE LOS MOZOS, José Luis. "Pago o cobro de lo indebido". Revista de Derecho Privado. Op. cit., p. 659.

${ }^{51}$ Salvat considera que el error debe ser excusable, basándose en el artículo 929 del Código Civil argentino. SALVAT, Raymundo. Tratado de derecho civil argentino. Obligaciones en general. 3. ${ }^{a}$ edición. Buenos Aires: Librería y Casa Editora de Jesús Menéndez, 1935, p. 607. 
por una injustificada negligencia; la razón de la repetibilidad del pago hecho por error estriba en cambio en la necesidad de impedir que nadie se enriquezca con lo ajeno, y en él es tan fuerte la gravitación de la equidad que no puede contrariarla la falta de excusa suficiente, en quien es víctima del empobrecimiento. ${ }^{52}$

El error irrelevante: el pago anticipado por error

Hay casos de error en elementos que no son trascendentes para el ordenamiento jurídico; es decir, son errores irrelevantes.

El Código Civil argentino ${ }^{53}$ considera como un supuesto típico de atribución patrimonial por error accidental el pago anticipado; vale decir, el pago efectuado antes del vencimiento del plazo suspensivo.

El artículo 180 del CC establece: "El deudor que pagó antes del vencimiento del plazo suspensivo no puede repetir lo pagado. Pero, si pagó por ignorancia del plazo, tiene derecho a la repetición".

Este artículo tiene como antecedente el texto derogado del artículo 571 del Código Civil argentino. En efecto, este artículo del Código de Vélez disponía: "El deudor de la obligación, que ha pagado antes del plazo, se supone que conocía el término, y no puede repetir lo pagado; pero si lo ha hecho por ignorancia del plazo, habría lugar a la repetición".

No obstante, la Ley 17.711 ha modificado dicho artículo, el que ahora señala: "El deudor de la obligación que ha pagado antes del plazo no puede repetir lo pagado", con lo cual se consagra la irrepetibilidad de lo pagado por considerar que el error, en ese caso, sería irrelevante.

El supuesto del pago antes del vencimiento del plazo suspensivo debe ser distinguido del pago efectuado antes del cumplimiento de la condición suspensiva, regulado en el último párrafo del artículo 173 del

${ }^{52}$ CAZEAUX, Pedro y Félix A. TRIGO REPRESAS. Compendio de derecho de las obligaciones. Tomo II. Op. cit., p. 519.

53 Vigente artículo 571 del Código Civil argentino. 
CC: "El deudor puede repetir lo que hubiese pagado antes del cumplimiento de la condición suspensiva o resolutoria".

En efecto, en el caso de la condición suspensiva, esta suspende la producción de los efectos del acto jurídico; por tanto, un pago efectuado antes del cumplimiento de la condición es un pago "no debido", pues no existe relación obligatoria. En cambio, en una relación obligatoria sujeta a plazo, lo que se encuentra suspendido es la exigibilidad.

En el caso de la condición resolutoria, una vez que se verifique estaríamos frente a un caso de condictio ob causam finitam y, por tanto, lo que se hubiese pagado mientras ella se encontraba pendiente debe ser restituido sobre la base del pago indebido.

El artículo 180 del CC se refiere a la "ignorancia", la cual debe ser diferenciada del error. Ello parece ser aceptado por el CC cuando, en el artículo 906, al referirse a la posesión legítima de buena fe, distingue la "ignorancia" del "error de hecho o de derecho".

El error ha sido definido como "falsa o distorsionada representación de la realidad", ${ }^{54}$ mientras que la ignorancia es entendida como la "absoluta falta de conocimiento sobre la realidad". ${ }^{55}$

\section{La prueba del error}

La carga de la prueba del error corresponde a quien pretende haber efectuado la atribución patrimonial sin causa. Así, teniendo en cuenta el artículo 1229 del $\mathrm{CC}_{,}^{56}$ quien pretende haber efectuado la atribución

${ }^{54}$ ROSSELLO, Carlo. "L'errore nel contratto. Artt. 1427-1433", en Il Codice Civile. Commentario. Milano: Giuffrè, 2004, p. 5.

55 ROSSELLO, Carlo. "L'errore nel contratto. Artt. 1427-1433", en Il Codice Civile. Commentario. Op. cit., p. 6.

56 "Artículo 1229.- La prueba del pago incumbe a quien pretende haberlo efectuado". No obstante, la referencia al artículo 1229 no es exacta, pues no estaríamos en estricto frente a un pago. Más adecuado nos parece el artículo 1900 del Código Civil español (del cobro de lo indebido), que señala: “La prueba del pago incumbe al que pretende haberlo hecho. También corre a su cargo la del error con que lo realizó...". 
patrimonial debe probar haberla hecho y, además, debe probar el error: "Artículo 1273.- Corre a cargo de quien pretende haber efectuado el pago probar el error con que lo hizo...".

La prueba del error es innecesaria cuando:

1) El accipiens niega haber recibido la atribución patrimonial y luego esta resulta probada: "Artículo 1273.- (...) a menos que el demandado negara haber recibido el bien que se le reclame. En este caso, justificada por el demandante la entrega, queda relevado de toda otra prueba. Esto no limita el derecho del demandado para acreditar que le era debido lo que se supone recibió...".

En este caso, la negativa del accipiens constituye un indicio de que la misma fue efectuada por error.

2) Se realiza una atribución patrimonial que nunca se debió o que ya estaba pagada: "Artículo 1273.- (...). Sin embargo, se presume que hubo error en el pago cuando se cumple con una prestación que nunca se debió o que ya estaba pagada. Aquel a quien se pide la devolución, puede probar que la entrega se efectuó a título de liberalidad o por otra causa justificada".

$\mathrm{Al}$ respecto, debe tenerse en cuenta que la doctrina italiana, sobre la base de lo dispuesto en el Codice Civile, distingue el pago indebido objetivo del subjetivo. ${ }^{57}$ Se tiene un pago indebido objetivo (indebitum ex re) cuando el solvens realiza una atribución patrimonial sobre la base de un título inexistente o ineficaz. Como señala Barbero, se tiene un pago indebido subjetivo (indebitum subjetivo) "si la relación existe, y existe válidamente, pero no entre las personas entre las cuales se ha realizado el pago". ${ }^{58} \mathrm{El}$ autor italiano distingue dos especies de indebitum subjetivo:

${ }^{57}$ En España, DE LOS MOZOS, José Luis. "Pago o cobro de lo indebido". Revista de Derecho Privado. Op. cit., p. 656.

58 BARBERO, Domenico. Sistema del derecho civil patrimonial. Tomo IV. Op. cit., p. 686. 
1) Ex persona accipientis, en la que existe la obligación del solvens, pero no respecto al accipiens;

2) Ex persona solventis, en la que existe el crédito del accipiens, pero no frente al solvens.

La diferencia radica en que en el pago indebido objetivo no se requiere el error del solvens. $\mathrm{O}$, como precisa Barbero, ${ }^{59}$ en el pago indebido objetivo hay una presunción de error.

De la lectura del artículo 1267 del CC podría generarse una confusión. Por un lado, la expresión: "el que por error de hecho o de derecho", permitiría afirmar que en el CC el pago indebido siempre es subjetivo. Por otro lado, los dos supuestos donde se produce una presunción de error permitirían afirmar que, en dichos casos, se consagra un pago indebido objetivo. No obstante, debe tenerse presente que se trata de presunciones iuris tantum, por tanto, de un supuesto de inversión de carga de la prueba, por lo que el demandado podría oponer la inexistencia del error. Por consiguiente, puede afirmarse que en nuestro CC el pago indebido es siempre un pago por error.

El ejemplo típico para el artículo 1273 del CC sería el contrato nulo. En el caso del contrato que es anulado por error, conforme al inciso 2 del artículo 221 del CC, deberá probarse el error como vicio de la voluntad. No obstante, si se realizó la atribución patrimonial, conforme al artículo 1273 se presumirá que esta se realizó por error, ello teniendo en cuenta el primer párrafo del artículo 222 del CC: "El acto jurídico es nulo desde su celebración, por efecto de la sentencia que lo declare...".

\section{El deber de restitución: su alcance y contenido}

Al producirse una atribución patrimonial sin causa por error, encontramos un sujeto que se empobrece (solvens) y un sujeto que se enriquece (accipiens). Así, sobre la base del principio general del enriquecimiento sin causa, quien recibe (accipiens) indebidamente un bien determinado, sea de buena o mala fe, está obligado a la restitución (condictio ex certa

59 BARBERO, Domenico. Sistema del derecho civil patrimonial. Tomo IV. Op. cit., p. 687. 
re). Como ya se vio, se trata de una fuente heterónoma de relaciones obligatorias.

\section{Sujetos de la repetición}

Titular del derecho de repetición es el solvens, es decir, quien realiza la atribución patrimonial. Si quien realizó la atribución patrimonial es el representante, entonces quien tiene el derecho a la repetición es este.

El pago indebido no presupone la propiedad; por eso, no hay necesidad de que el solvens pruebe ser propietario. En tal sentido, el solvens dominus y el solvens non dominus ${ }^{60}$ están legitimados para ejercitar la repetición de lo pagado.

En el indebitum ex persona parte debitoris, es decir, en el pago efectuado por el solvens creyéndose deudor, el titular del derecho de repetición es el solvens. Si, en cambio, el pago es cumplido por encargo del presunto deudor, Bianca, basándose en el artículo 1705 del Código Civil italiano, menciona que el presunto deudor "puede subrogarse en los derechos del mandatario frente a los terceros salvo que ello pueda perjudicar los derechos del mandatario frente al mismo mandante. Si, por consiguiente, el mandatario hubiera recibido los medios para efectuar el pago, corresponderá al mandante ejercitar el derecho de repetición". ${ }^{61}$

El último párrafo del artículo 1705 del Código Civil italiano, referido al mandato sin representación, señala: "Los terceros no tienen ninguna relación con el mandante. Sin embargo el mandante sustituyéndose al mandatario, puede ejercitar los derechos de crédito derivados de la ejecución del mandato, salvo que ello pueda perjudicar los derechos atribuidos al mandatario..." (las cursivas son nuestras).

La parte subrayada no encuentra correlato en el CC; así, conforme al artículo 1809 del CC, ${ }^{62}$ el derecho de repetición corresponde al mandatario.

${ }^{60}$ En este sentido, BALLARÍN HERNÁNDEZ, Rafael. Op. cit., p. 154.

61 BIANCA, Massimo. Diritto civile. 5. Responsabilità. Op. cit., p. 798.

62 Artículo 1809.- El mandatario que actúa en nombre propio adquiere los derechos y asume las obligaciones derivadas de los actos que celebra en interés y por cuenta del mandante, aun cuando los terceros hayan tenido conocimiento del mandato. 
En el caso del pago al "acreedor aparente", este debe restituir la prestación al verdadero acreedor. El artículo 1225 del CC dispone: "Extingue la obligación el pago hecho a persona que está en posesión del derecho de cobrar, aunque después se le quite la posesión o se declare que no la tuvo".

Si bien el artículo no lo indica en forma expresa, ello se deriva del hecho de que dicho pago (al acreedor aparente) supone la liberación del deudor ("extingue la obligación"). El artículo 1189 del Código Civil italiano, referido al pago al acreedor aparente, señala en su segundo párrafo: "Quien ha recibido el pago está obligado a la restitución frente al verdadero acreedor, según las reglas establecidas para el pago indebido".

Un caso particular es el derecho de repetición del fiador: si este efectuara el pago al acreedor sin comunicarlo al deudor, y este, a su vez, también paga, entonces el fiador pierde el derecho de regreso frente al deudor. No obstante, tiene derecho de repetición contra el acreedor. En efecto, conforme al artículo 1892 del CC: "El fiador no tiene acción contra el deudor si, por haber omitido comunicarle el pago efectuado, éste ha cancelado igualmente la deuda. Lo expuesto es sin perjuicio del derecho de repetición del fiador contra el acreedor".

El CC no contiene una norma expresa como el artículo 2039 del Código Civil italiano, referido al pago indebido recibido por un incapaz: "El incapaz que ha recibido el pago indebido, aún si de mala fe, no está obligado a sino en los límites de aquello que ha recibido y ha sido convertido en su provecho".

El CC sólo tiene la norma relativa al pago al acreedor incapaz establecida en el artículo 1227: "El pago hecho a incapaces sin asentimiento de sus representantes legales, no extingue la obligación. Si se prueba que el pago fue útil para el incapaz, se extingue la obligación en la parte pagada".

Ello es confirmado por la norma de la repetición derivada de la anulación del acto jurídico en el artículo 228 del CC: "Nadie puede repetir lo que pagó a un incapaz en virtud de una obligación anulada, sino en la parte que se hubiere convertido en su provecho".

\section{Objeto de la repetición}

La restitución tiene como objeto el bien entregado indebidamente. Si la atribución patrimonial consiste en una suma de dinero, debe ser 
restituida igual suma. Si consiste en un bien determinado, debe restituirse in natura si subsiste al momento de la pretensión. ${ }^{63}$

\section{El deber de restitución: su contenido}

El contenido del deber de restitución dependerá de la buena o de la mala fe del accipiens; es decir, de si este recibe el bien en la creencia de que le era debido, o de si lo recibe siendo consciente del error del solvens.

a) El contenido del deber de restitución en la atribución patrimonial sin causa por error del solvens recibida por el accipiens de buena fe

Debe advertirse que cuando el solvens "entrega a otro algún bien o cantidad en pago", está realizando la tradición del bien; por tanto, conforme al artículo 900 del CC, el solvens transfiere la posesión del bien al accipiens, de tal manera que este es, ante todo, un poseedor. ${ }^{64}$

Dado que se trata de una atribución patrimonial sin causa, el accipiens recibe la posesión ilegítima; y si este cree que le es debido el bien, entonces es un poseedor de buena fe: ${ }^{65}$ "Artículo 1271.- El que de buena fe acepta un pago indebido debe restituir los intereses o frutos percibidos y responde de la pérdida o deterioro del bien en cuanto por ellos se hubiese enriquecido".

63 Como veremos, la restitución in natura no será posible si el bien ha sido consumido o se ha perdido o ha sido eficazmente enajenado a un tercero.

64 “Artículo 900.- La posesión se adquiere por la tradición, salvo los casos de adquisición originaria que establece la ley". Conforme a Ballarín Hernández, "La indebiti solutio transfiere siempre la posesión de lo entregado". BALLARÍN HERNÁNDEZ, Rafael. Op. cit., p. 153.

${ }^{65}$ Artículo 906.- La posesión ilegítima es de buena fe cuando el poseedor cree en su legitimidad, por ignorancia o error de hecho o de derecho sobre el vicio que invalida su título. 
Respecto a los frutos y los intereses ${ }^{66}$

De acuerdo con el artículo 1271 del CC, el accipiens debe restituir:

- El bien recibido.

- Cuando el bien recibido sea dinero, debe restituir además los intereses percibidos.

- Cuando se trata de cualquier otro bien (distinto al dinero) que sea fructífero, ${ }^{67}$ debe restituir además los frutos percibidos.

Este artículo debe ser concordado con el artículo 908 del CC: “El poseedor de buena fe hace suyos los frutos".

Pues bien, si el poseedor de buena fe hace suyos los frutos, debe entenderse que cuando el artículo 1271 señala que el accipiens debe restituir los frutos percibidos, serán aquellos que se hubieran percibido desde el momento en que es notificado con la demanda, ${ }^{68}$ aunque, con mayor precisión, deberá concordarse con el artículo 907 del CC: “La buena fe dura mientras las circunstancias permitan al poseedor creer que posee legítimamente $\mathrm{o}$, en todo caso, hasta que sea citado en juicio, si la demanda resulta fundada".

66 Si bien para el CC los intereses constituyen frutos (se trataría de frutos civiles de acuerdo con el artículo 891 del CC), en las normas relativas al pago indebido se les brinda un tratamiento diferenciado; ver MAZZONI, Cosimo Marco. "Frutti civili e interessi di capitale". Quaderni di Giurisprudenza Comérciale 75. Milano: Giuffrè, 1985. Para una crítica de la posición que considera a los intereses como frutos, ver FERNÁNDEZ CRUZ, Gastón. “La naturaleza jurídica de los intereses: punto de conexión entre derecho y economía". Derecho 45. Lima, diciembre de 1991, p. 177 y ss.

67 Podría hablarse de "bienes productivos" para referirse a aquellos bienes caracterizados por la natural aptitud de producir bienes ("bienes productivos en sentido estricto"). Ver, al respecto, TANZI, Mauricio. Godimento del bene produttivo e impresa. Milano: Giuffrè, 1998.

${ }_{68}$ En este sentido, el artículo 2033 del Código Civil italiano. 
Así, el artículo 1271 debe leerse en el entendido de que el accipiens de buena fe debe restituir los frutos percibidos desde el momento en que se percate de que el bien no le era debido, o, en todo caso, desde la fecha de la notificación de la demanda. Y como desde ese momento se considera poseedor de mala fe, deberá concordarse con el artículo 910 del CC y, por tanto, "si no existen [los frutos], a pagar su valor estimado al tiempo que los percibió o debió percibir": "Artículo 910.- El poseedor de mala fe está obligado a entregar los frutos percibidos y, si no existen, a pagar su valor estimado al tiempo que los percibió o debió percibir".

Respecto a los intereses, la norma obliga al accipiens de buena fe a restituir los intereses percibidos. Adviértase que si este hubiera prestado el dinero recibido y, conforme al artículo 1243 del CC, hubiera fijado como tasa de interés convencional compensatoria la máxima permitida por el Banco Central de Reserva del Perú, entonces tendría que restituir los intereses percibidos con dicha tasa. La tasa máxima, en obligaciones dinerarias contraídas en moneda extranjera, es la "tasa promedio del sistema financiero para créditos a la microempresa", 69 que a la fecha es, aproximadamente, $46 \%$ efectivo anual. ${ }^{70}$

Si el accipiens de buena fe no hubiera percibido intereses, entonces deberá devolver aquellos que se hubieran percibido utilizando la diligencia ordinaria. Esto puede resultar complicado de determinar, puesto que el costo de oportunidad del dinero no es único; es decir, hay tasas de rendimiento alternativas (por ejemplo: depósitos a plazo fijo, oro, etcétera). ¿Cuál se habría percibido utilizando la diligencia ordinaria?

Respecto a la pérdida o deterioro del bien

De acuerdo con el artículo 1271 del CC, el accipiens responde de la pérdida o deterioro del bien en cuanto por ellos se hubiese enriquecido.

69 Circular 021-2007-BCRP, del 28 de septiembre del 2007. En la misma circular se indica la tasa máxima para obligaciones en moneda extranjera.

70 Esto es importante tenerlo en cuenta para cuando se aborde el caso del accipiens de mala fe. 
¿Cuáles son las consecuencias si el bien se pierde en posesión del accipiens de buena fe, es decir, antes de la restitución?

El accipiens debe restituir al solvens el bien que ha recibido. Estamos, entonces, frente a una relación obligatoria con prestación de dar bien cierto (se trata del bien que el accipiens ha recibido) con función restitutoria y, por tanto, sujeta al riesgo de la imposibilidad sobreviniente de la prestación (pérdida del bien) antes de la entrega. En tal sentido, debemos preguntarnos: ¿cuáles son las consecuencias de la pérdida del bien antes de la devolución?

Los casos de pérdida del bien están previstos en el artículo 1137 del $\mathrm{CC} .{ }^{71}$ La pérdida del bien genera la imposibilidad sobreviniente de la prestación y, por tanto, la liberación del accipiens de restituir el bien in natura, aun si la pérdida se produjera por causas imputables a él; pero también genera una lesión del derecho de propiedad, que, de ser imputable al accipiens, lo obligaría a responder. Obviamente, esta lesión se causa al propietario; por eso, se debe indemnizar al propietario y no al solvens non dominus.

Como regla general, el accipiens de mala fe no responde por la lesión del derecho de propiedad, ni siquiera por causas a él imputables. La buena fe da lugar a una atenuación de la responsabilidad del accipiens, lo que, según Levi, genera "un injustificado tratamiento respecto de los daños que sufre el solvens, cuando la imposibilidad de la prestación dependa de hecho propio". ${ }^{72}$

El artículo 1271 del CC mantiene la regla generalmente aceptada de que el accipiens de buena fe no responde por la lesión del derecho de propiedad, incluso por causas a él imputables; no obstante, precisa que "responde de la pérdida (...) del bien en cuanto por ello se hubiese enriquecido". Así por ejemplo, si el accipiens dentro de una actividad de

71 Artículo 1137.- La pérdida del bien puede producirse:

1. Por perecer o ser inútil para el acreedor por daño parcial.

2. Por desaparecer de modo que no se tenga noticias de él o, aún teniéndolas, no se pueda recobrar.

3. Por quedar fuera del comercio.

72 LEVI, Giulio. Op. cit., p. 160. 
empresa hubiera transformado los bienes recibidos, tendrá que pagar su valor. ${ }^{73}$ Sería el caso del vinicultor que recibe uvas que son transformadas en vino. ${ }^{74} \mathrm{O}$ el caso del accipiens que ha conseguido el resarcimiento del daño por parte de un tercero responsable de la pérdida del bien. Este párrafo se sustenta en el principio del enriquecimiento sin causa, puesto que el enriquecimiento que pudiera obtener el accipiens de buena fe como consecuencia de la pérdida del bien, no le correspondería a él, sino al propietario.

De acuerdo con Bianca, en este caso, "el valor debería ser determinado con referencia al momento de la pérdida, pues es en la oportunidad en la que el accipiens ha consumado la adquisición, realizando su enriquecimiento". ${ }^{75}$ No obstante, opinamos que en el caso peruano debería aplicarse el artículo 1236 del CC. ${ }^{76}$

Entendemos que la pérdida debe ocurrir mientras perdure la buena fe. Así, si el bien se pierde cuando ya el accipiens conoce la ilegitimidad de la posesión, entonces se aplicará el artículo 1269 del CC.

\section{Bienes genéricos y consumibles}

¿Qué ocurre si el bien entregado indebidamente es uno consumible? ¿Se trata de una obligación genérica restitutoria? Castelblanco Koch señala que

... las obligaciones restitutorias de cosa genérica que no sea dinero están formadas por aquéllas en las cuales se adeuda en retorno un bien o individuo indeterminado de una clase o género determinado que no

73 BIANCA, Massimo. Diritto civile. 5. La responsabilità. Op. cit., p. 800.

74 Téngase en cuenta el primer párrafo del artículo 937 del CC: “El objeto que se hace de buena fe con materia ajena pertenece al artífice, pagando el valor de la cosa empleada...".

75 BIANCA, Massimo. Diritto civile. 5. La responsabilità. Op. cit., p. 801.

${ }^{76}$ Artículo 1236.- Cuando deba restituirse el valor de una prestación, aquel se calcula al que tenga el día del pago, salvo disposición legal diferente o pacto en contrario. 
sea dinero; es decir, que lo que es objeto de la prestación es "cualquier individuo del género, con tal que sea de una calidad a lo menos mediana" (...); librándose, por tanto, el deudor con la entrega, ya no de cosa específica, sino de cualquiera de las que conforman el género de lo adeudado. ${ }^{77}$

No obstante, resulta oportuno recordar, con Díez-Picazo, que "el carácter genérico de la obligación pertenece más a la órbita de la configuración por los particulares de sus recíprocas relaciones que a la esfera de la normal y objetiva consideración de los bienes en su comercialización" ${ }^{78}$

En tal sentido, nos encontraremos frente a una obligación de dar bien genérico cuando las partes no han designado el bien debido en su individualidad, sino solo por los caracteres que determinan su pertenencia a un género. ${ }^{79}$ Pero no nos encontraremos frente a esta clase de obligaciones, por ejemplo, en los supuestos de resolución de una relación obligatoria $^{80}$ configurada inicialmente como genérica.

Nuestra afirmación se basa, precisamente, en que la individualización (elección) habría convertido lo genérico en específico y, por tanto, al resolverse la relación obligatoria estaríamos frente a una obligación restitutoria de bien cierto (debe restituirse el bien entregado). Por ejemplo: Primus se obliga a entregarle a Secundus un perro pastor alemán. Sin duda, nos encontramos frente a una obligación genérica. Producida la elección, será, por ejemplo, Ringo el perro entregado. Al resolverse la relación obligatoria, Secundus deberá devolver a Ringo y no a cualquier

77 CASTELBLANCO KOCH, Mauricio Javier. Las obligaciones restitutorias del Código Civil y la inflación. Santiago: Editorial Jurídica de Chile, 1979, p. 47.

78 DÍEZ-PICAZO, Luis. Fundamentos del derecho civil patrimonial. Volumen II. Op. cit., p. 293.

79 "Artículo 1142.- Los bienes inciertos deben indicarse, cuando menos, por su especie y cantidad". Ver, al respecto, SÁNCHEZ CALERO, Francisco Javier. “Las obligaciones genéricas". Revista de Derecho Privado. Madrid, 1980, p. 645.

80 Si bien se habla usualmente de resolución del contrato, debe tenerse en cuenta que son los efectos los que se extinguen, es decir, la relación obligatoria y no el contrato mismo, que, como hecho, perdura en el tiempo. 
perro pastor alemán. En todo caso, si Ringo hubiera muerto, se considerará que se produjo la pérdida del bien.

Una cuestión distinta está determinada por la naturaleza consumible del bien. Así por ejemplo, en el caso del mutuo, el artículo 1648 del CC prescribe que el mutuatario debe devolver, no los mismos bienes consumibles que le han sido entregados, sino otros de la misma especie, calidad o cantidad. No existe norma específica para las obligaciones restitutorias de bienes consumibles distintas al mutuo.

En el caso de los efectos restitutorios, si se trata de bienes consumibles, el accipiens de buena fe deberá restituir, en principio, el mismo bien entregado; y si ya hubiera sido consumido, entonces deberá restituir el valor del bien.

¿Qué valor? En el caso de la resolución, se aplicaría el tercer párrafo del artículo 1372 del CC: "Por razón de la resolución, las partes deben restituirse las prestaciones en el estado en que se encontraran al momento indicado en el párrafo anterior, y si ello no fuera posible debe reembolsarse en dinero el valor que tenían en dicho momento...".

De acuerdo con la norma citada, el valor que debe ser restituido es el que tenía el bien al momento en que se produce la causal que motiva la resolución (supongamos, el incumplimiento). Si se tratara, por ejemplo, de un caso de nulidad, anulabilidad o rescisión, se aplicaría el artículo 1236 del CC: "Cuando deba restituirse el valor de una prestación, aquel se calcula al que tenga el día del pago, salvo disposición legal diferente o pacto en contrario".

¿Por qué la diferencia? ¿Por qué en caso de resolución por incumplimiento se tendrá en cuenta el valor del bien al momento de dicho incumplimiento, y en caso de nulidad, anulabilidad o rescisión se tendrá en cuenta el valor del bien al momento del pago? Desde nuestro punto de vista, la solución adecuada es la del artículo 1236 del CC, es decir, se debe determinar el valor del bien según el que tenga el día del pago, ${ }^{81}$ tomando en consideración el valor de reposición, es decir, el precio de mercado que habría que pagar para sustituir determinado bien por otro de iguales características.

${ }^{81}$ Con mayor precisión, sería el valor del bien al momento de la sentencia. 
b) El contenido del deber de restitución en la atribución patrimonial sin causa por error del solvens recibida por el accipiens de mala $\mathrm{fe}$

Dado que se trata de una atribución patrimonial sin causa, el accipiens recibe una posesión ilegítima; y si este es consciente del error del solvens, entonces es un poseedor de mala fe:

Artículo 1269.- El que acepta un pago indebido, si ha procedido de mala fe, debe abonar el interés legal cuando se trate de capitales o frutos percibidos o que ha debido percibir cuando el bien recibido los produjera, desde la fecha del pago indebido.

Además, responde de la pérdida o deterioro que haya sufrido el bien por cualquier causa, y de los perjuicios irrogados a quien lo entregó, hasta que lo recobre.

Puede liberarse de esta responsabilidad, si prueba que la causa no imputable habría afectado al bien del mismo modo si hubiera estado en poder de quien lo entregó.

Sintetizando lo señalado en este artículo del CC, puede decirse que el accipiens debe restituir:

- El bien recibido.

- Cuando el bien recibido sea dinero (capitales), ${ }^{82}$ debe pagar, además, el interés legal desde la fecha del pago indebido.

82 El término capitales del artículo 1269 es inadecuadamente utilizado como sinónimo de dinero. El capital puede estar constituido por bienes de existencia permanente (por ejemplo, un inmueble) o por bienes consumibles o fungibles, entre ellos, el dinero. Entendemos que el legislador se ha querido referir sólo al dinero. Ver, al respecto, BOHM-BAWERK, Eugen von. Capital e interés. México: Fondo de Cultura Económica, 1986, p. 27 y ss. 
- Cuando se trate de otros bienes (distintos del dinero) que sean fructíferos, debe restituir los frutos percibidos o que debió percibir, desde la fecha del pago indebido.

Además, el accipiens responde:

- De la pérdida que haya sufrido el bien por cualquier causa.

- De los perjuicios irrogados al solvens, hasta que recobre el bien.

Respecto a los frutos

El artículo 1269 del CC establece que el accipiens de mala fe debe restituir los "frutos percibidos o que ha debido percibir cuando el bien recibido los produjera, desde la fecha del pago indebido".

Esta norma debe ser concordada con el artículo 910: "El poseedor de mala fe está obligado a entregar los frutos percibidos y, si no existen, a pagar su valor estimado al tiempo que los percibió o debió percibir".

En tal sentido, el accipiens de mala fe debe:

- Restituir los frutos percibidos, y si ya no existen, pagar su valor estimado al tiempo que los percibió.

- Si el bien no hubiera percibido frutos, entonces debe pagar el valor de los que habría podido percibir el bien si utilizaba la diligencia ordinaria.

El pago del valor de los frutos que habría podido percibir se hace a título de resarcimiento por la inercia culposa del accipiens de hacer fructífero el bien. La culpa del accipiens consiste en haber dejado improductivo dicho bien, incumpliendo su deber de usar la diligencia debida. ${ }^{83}$

${ }_{83}$ Ver LEVI, Giulio. Op. cit., p. 28. 
Respecto a los intereses

Artículo 1269.- El que acepta un pago indebido, si ha procedido de mala fe, debe abonar el interés legal cuando se trate de capitales...

La redacción de este artículo del CC parece señalar que si la atribución patrimonial sin causa consiste en "capitales" (léase dinero), el accipiens de mala fe "debe pagar el interés legal", mientras que si consiste en "otros bienes", debe pagar los frutos "percibidos o que ha debido percibir usando la diligencia ordinaria, desde la fecha del pago indebido". Del mismo modo - como se ha visto - , en el caso del artículo 1271 del CC, el accipiens de buena fe debe restituir los "intereses y frutos percibidos". ¿Por qué el accipiens de mala fe no debe restituir los intereses percibidos?

Sin duda, el artículo 1269 brinda al accipiens de mala fe un trato más beneficioso en materia de intereses que de frutos; e incluso - lo que es más absurdo-, en materia de intereses, un trato más beneficioso que al accipiens de buena fe.

Como se ha visto, el accipiens de buena fe debe restituir los intereses percibidos, lo que supondría, por ejemplo, restituir intereses sobre la base de la "tasa promedio del sistema financiero para créditos a la microempresa" (aproximadamente, 46\% efectivo anual), que es lo máximo que podría cobrar si hubiera prestado el dinero recibido indebidamente. En cambio, el accipiens de mala fe debe pagar sólo el interés legal, aunque hubiese percibido intereses mayores. El interés legal es la tasa pasiva moneda nacional (TIPMN), ${ }^{84}$ que a la fecha es aproximadamente $3 \%$ efectivo anual.

En tal sentido, el accipiens de mala fe podría haber percibido intereses sobre la base de la tasa máxima permitida por el Banco Central de

${ }^{84}$ La tasa del interés legal, conforme a la Circular 021-2007-BCRP, de 28 de septiembre del 2007, es la TIPMN, es decir, la tasa pasiva moneda nacional; es la tasa promedio de las tasas pagadas sobre los depósitos en moneda nacional -incluidos aquellos a la vista - por los bancos y financieras. Para el caso de moneda extranjera, sería la TIPMEX. 
Reserva del Perú, que es la "tasa promedio del sistema financiero para créditos a la microempresa", intereses que no estaría obligado a restituir, como sí ocurre con el accipiens de buena fe. El artículo 1269 del CC sólo le impone al accipiens de mala fe pagar el interés legal.

\section{Respecto a la pérdida del bien}

¿Cuáles son las consecuencias si el bien se pierde en posesión del accipiens de mala fe, es decir, antes de la restitución?

Como se ha dicho, estamos frente a una relación obligatoria con prestación de dar bien cierto con función restitutoria; por tanto, sujeta al riesgo de la imposibilidad sobreviniente de la prestación (pérdida del bien) antes de la entrega.

La pérdida del bien genera la imposibilidad sobreviniente de la prestación y, por tanto, la liberación del accipiens de restituir el bien in natu$r a$, aun si la pérdida se produjera por causas a él imputables. Pero la pérdida del bien que debía ser restituido genera una lesión del derecho de propiedad, de la cual deberá responder, incluso, si la pérdida se produce por causas no imputables ${ }^{85}$ al accipiens. Obviamente, esta lesión se causa al propietario, titular del interés lesionado, y no al solvens non dominus.

El artículo 1269 del CC señala que el accipiens de mala fe "responde de la pérdida o deterioro que haya sufrido el bien por cualquier causa, y de los perjuicios irrogados a quien lo entregó, hasta que lo recobre"; pero, también, que "puede liberarse de esta responsabilidad, si prueba que la causa no imputable habría afectado el bien del mismo modo si hubiera estado en poder de quien lo entregó".

Este artículo debe ser concordado con el artículo 909 del mismo código: “El poseedor de mala fe responde de la pérdida o detrimento del

85 El Código Civil habla de "caso fortuito o fuerza mayor", que solo constituye uno de los supuestos de "causa no imputable". Ver, al respecto, VISINTINI, Giovanna. Responsabilidad contractual y extracontractual. Lima: Ara, 2002, p. 66 y ss. Ver, también, BIANCA, Massimo. Diritto civile. 5. La responsabilità. Op. cit., p. 30 y ss. 
bien aun por caso fortuito o fuerza mayor, salvo que este también se hubiese producido en caso de haber estado en poder de su titular".

Como se puede advertir, el artículo 1269 indica que el accipiens de mala fe:

1) "responde de la pérdida o deterioro que haya sufrido el bien", y

2) "de los perjuicios irrogados a quien lo entregó, hasta que lo recobre".

Sin embargo, la redacción genera algunas dudas. Veamos.

Se entiende que cuando el artículo citado señala que el accipiens de mala fe responde de la pérdida o deterioro que haya sufrido el bien, se refiere a que debe restituir el valor de dicho bien y, por tanto, deberá tenerse en cuenta el artículo 1236 del CC: "Cuando deba restituirse el valor de una prestación, aquel se calcula al que tenga al día del pago, salvo disposición legal diferente o pacto en contrario".

Queda claro que el valor del bien constituye un contenido típico del daño emergente $y$, además, que le corresponde al propietario del bien, titular del interés lesionado. Pero el artículo 1269 también dispone que el accipiens de mala fe responde "de los perjuicios irrogados a quien lo entregó, hasta que lo recobre", ${ }^{86}$ lo cual supone que el accipiens responde por todos los daños causados y no solo por el daño emergente.$^{87} \mathrm{No}$ obstante, debe precisarse que responde frente al propietario del bien; por tanto, cuando el artículo expresa: "a quien lo entregó", debe entenderse que se refiere, en principio, al solvens dominus. ${ }^{88}$

86 De acuerdo con Levi, "el accipiens de mala fe, además de restituir la cosa in natura, tiene la obligación de resarcir los daños, pues la recepción de la cosa con mala fe constituye un hecho ilícito". LEVI, Giulio. Op. cit., p. 159.

${ }_{87}$ El daño emergente y el lucro cesante son los dos aspectos fundamentales del daño resarcible.

88 También podría lesionar el interés del solvens non dominus. Imaginemos, por ejemplo, al usufructuario que entrega el bien en arrendamiento para percibir la renta, y el contrato de arrendamiento es declarado nulo: en este caso, la pérdida del bien también constituye un daño injusto (lesión de un interés jurídicamente protegido en la vida de relación). “Además de la lesión dolosa o culposa de la 
El párrafo que señala que el accipiens de mala fe responde de la pérdida o deterioro que haya sufrido el bien por cualquier causa, y de los perjuicios irrogados a quien lo entregó, hasta que lo recobre, genera confusión. Una primera lectura parecería indicar que el accipiens de mala fe responde de los perjuicios sólo en caso de pérdida del bien. Pero ello no es lógico, pues si el bien se ha perdido, no tiene sentido decir que se responde por los perjuicios "hasta que lo recobre"; en realidad, el accipiens de mala fe responde de los daños causados, ${ }^{89}$ por su sola mala fe.

De acuerdo con Díez-Picazo,

El accipiens de mala fe responde de los menoscabos y daños que la cosa hubiera sufrido por cualquier causa, toda vez que su mala fe le coloca en situación de mora respecto de la restitución, lo que hace que sean de su cargo los riesgos. Responde, asimismo y por la misma razón, de los perjuicios que la falta de la cosa ocasione al que la entregó hasta que la recobre..$^{90}$

¿El accipiens de mala fe se encuentra automáticamente en mora (mora debitoris) de acuerdo con nuestro CC? Como se sabe, el artículo 1333 del CC consagra la mora por interpelación como regla, y sólo como excepción la mora automática. Los efectos atribuidos al accipiens de mala fe por el artículo 1269 del CC: i) el "pago de intereses legales (...) desde la

propiedad, constituye daño injusto la lesión dolosa o culposa de los derechos reales de goce sobre una cosa ajena (superficie, usufructo, uso, habitación). En estos casos, la destrucción o el deterioro de la cosa causan daños tanto al propietario y al titular del derecho real limitado, dando lugar a distintas pretensiones resarcitorias en razón del valor de las respectivos derechos". BIANCA, Massimo. Diritto civile. 5. La responsabilità. Op. cit., p. 597.

${ }^{89}$ El artículo 1269 se refiere a "perjuicios" y no a "daños", cosa curiosa, teniendo en consideración que nuestro CC utiliza la expresión "daños y perjuicios"; el artículo 1336, por ejemplo, habla de "daños y perjuicios". La doctrina moderna solo se refiere simplemente a "daños".

90 DÍEZ-PICAZO, Luis. Fundamentos del derecho civil patrimonial. Volumen II. Op. cit., p. 519. 
fecha del pago indebido"; ii) la responsabilidad por la pérdida del bien por cualquier causa; y iii) la responsabilidad por los perjuicios causados; nos llevan al artículo 1336 del CC:

Artículo 1336.- El deudor constituido en mora responde de los daños y perjuicios que irrogue por el retraso en el cumplimiento de la obligación y por la imposibilidad sobreviniente, aun cuando ella obedezca a causa que no le sea imputable. Puede sustraerse a esta responsabilidad probando que ha incurrido en retraso sin culpa, o que la causa no imputable habría afectado la prestación, aunque se hubiese cumplido oportunamente.

Así, los efectos que se atribuyen al accipiens de mala fe son los que le corresponden al deudor en mora, por lo que opinamos que aquel se encuentra en situación de mora (mora debitoris). Se trata de un supuesto de "mora legal".

Para Gagliardo, se trataría de un caso de mora legal, es decir, uno de "aquellos casos contemplados por la ley en los cuales la mora se produce por imperio de ella, sin que sea menester el requerimiento del deudor"..$^{11}$

Si aceptamos que el accipiens de mala fe se encuentra en situación de mora (mora debitoris) desde el momento en que recibe el bien, entenderemos lo que advierte Visintini: "el deudor moroso se ha colocado en condición de exponer el objeto de la prestación, teniéndolo en su pose-

91 GAGLIARDO, Mariano. La mora en el derecho civil y comercial. Su estructura y sus alcances. Buenos Aires: Abeledo-Perrot, 1979, p. 70. Opina lo mismo BUSTAMANTE ALSINA, Jorge. Teoría general de la responsabilidad civil. 5. a edición. Buenos Aires: Abeledo-Perrot, 1987, p. 102. De acuerdo con el artículo 1333 del CC, no es necesaria la intimación para que la mora exista cuando "la ley o el pacto lo declaren expresamente". La exigencia de la declaración expresa podría generar alguna duda, pero creemos que si se le atribuyen los efectos de la mora del deudor, podemos decir: "Camina como pato, grazna como pato: debe ser un pato". 
sión en lugar de entregarlo, a un riesgo al cual no estaría expuesto, y es por esta razón que la regla en examen concede al deudor la prueba liberatoria [de] que la cosa habría igualmente perecido en posesión del acreedor". ${ }^{92}$

Conforme al artículo 1269 del CC, se agrava la responsabilidad del accipiens de mala fe. En efecto, si bien de acuerdo con el artículo 1317 del mismo código el deudor no responde de la pérdida o deterioro que haya sufrido el bien cuando ello ocurre por causas no imputables a él (recuérdese que el accipiens es deudor de quien entregó el bien), en el caso del pago recibido de mala fe el accipiens deberá responder aun por causa que no le sea imputable, en concordancia con el artículo 1336, según el cual el deudor constituido en mora responde "por la imposibilidad sobreviniente, aun cuando ella obedezca a causa que no le sea imputable". No obstante (artículo 1269), "puede liberarse de esta responsabilidad, si prueba que la causa no imputable habría afectado el bien del mismo modo si hubiera estado en poder de quien lo entregó".

¿Qué ocurre si el bien que debe ser restituido es una suma de dinero?

El accipiens de mala fe incurre de manera automática en mora (mora debitoris) desde la fecha del pago indebido, por lo que, conforme al artículo 1336 del CC, se le atribuyen los efectos de la mora debitoris: "El deudor constituido en mora responde de los daños y perjuicios que irrogue por el retraso en el cumplimiento de la obligación...".

Según el artículo 1324 del CC, ${ }^{93}$ las obligaciones de dar suma de dinero devengan el interés moratorio desde el día en que el deudor incurra en mora. Cuando las partes no han fijado convencionalmente la tasa de interés, debe abonarse la tasa del interés legal.

92 VISINTINI, Giovanna. "Inadempimento e mora del debitore. Artt. 1218-1222", en Il Codice Civile. Commentario. Diretto da Piero Schlesinger. Milano: Giuffrè, 1987, p. 457. La autora comenta el artículo 1221 del Código Civil italiano, similar al artículo 1336 del CC.

93 Artículo 1324.- Las obligaciones de dar sumas de dinero devengan el interés legal que fija el Banco Central de Reserva del Perú, desde el día en que el deudor incurra en mora, sin necesidad de que el acreedor pruebe haber sufrido daño alguno... 
Teniendo en cuenta que, de acuerdo con el artículo 1242 del CC, el interés es moratorio "cuando tiene por finalidad indemnizar la mora en el pago", ¿ello significa que si lo indebidamente pagado es dinero, los "perjuicios" a los que se refiere el artículo 1269 del CC son estos intereses moratorios?

Pero, si esto es así, ¿cómo lo concordamos con el primer párrafo del artículo 1269? Dicho párrafo dice que el accipiens de mala fe "debe abonar el interés legal cuando se trate de capitales"; y el párrafo siguiente del mismo artículo, que el accipiens de mala fe responde "de los perjuicios irrogados a quien lo entregó, hasta que lo recobre". Es decir, ¿deben pagarse dos veces los intereses legales? Insistimos, lo correcto habría sido imponer al accipiens de mala fe la obligación de restituir los intereses percibidos; y solo si el solvens lograra demostrar que hubiera percibido intereses mayores, podría reclamar por los perjuicios irrogados (por la diferencia). 


\section{Bibliografía}

ARGIROFFI, Carlo. Ripetizione di cosa determinata e acquisto "a domino" della proprietà. Milano: Giuffrè, 1980.

BALLARÍN HERNÁNDEZ, Rafael. El cobro de lo indebido. Perfiles institucionales y eficacia traslativa. Madrid: Tecnos, 1985.

BARBERO, Domenico. Sistema del derecho civil patrimonial. Tomo IV. Buenos Aires: Ediciones Jurídicas Europa-América, 1967.

BIANCA, Massimo. Diritto civile. 5. La responsabilità. Milano: Giuffrè, 1994.

BOHM-BAWERK, Eugen von. Capital e interés. México: Fondo de Cultura Económica, 1986.

BUSTAMANTE ALSINA, Jorge. Teoría general de la responsabilidad civil. 5. ${ }^{a}$ edición. Buenos Aires: Abeledo-Perrot, 1987.

BUSTAMANTE ALSINA, Jorge. Repetición del pago de lo que no se debe. Buenos Aires: Abeledo-Perrot, 1981.

Código Civil peruano de 1984.

CÁRDENAS QUIRÓS, Carlos. “Hacia la reforma del libro VI del Código Civil". Thémis 30.

CASTELBLANCO $\mathrm{KOCH}$, Mauricio Javier. Las obligaciones restitutorias del Código Civil y la inflación. Santiago: Editorial Jurídica de Chile, 1979.

CAZEAUX, Pedro y Félix A. TRIGO REPRESAS. Compendio de derecho de las obligaciones. Tomo II. La Plata: Librería Editora Platense, 1986.

CORRAL TALCIANI, Hernán Felipe. De la ignorancia de la ley. El principio de su inexcusabilidad. Santiago: Editorial Jurídica de Chile, 1987.

DE LOS MOZOS, José Luis. "Pago o cobro de lo indebido". Revista de Derecho Privado.

DÍEZ-PICAZO, Luis. Fundamentos del derecho civil patrimonial. Volumen I. 5. ${ }^{\text {a }}$ edición. Madrid: Civitas, 1996.

DÍEZ-PICAZO, Luis. "Los llamados contratos forzosos", en CÁRDENAS QUIRÓS, Carlos. Materiales de lectura del curso Derecho Civil Patrimonial II. Lima: Maestría en Derecho Empresarial de la Universidad de Lima.

FERNÁNDEZ CRUZ, Gastón. “La naturaleza jurídica de los intereses: 
punto de conexión entre derecho y economía". Derecho 45. Lima, diciembre de 1991.

GAGLIARDO, Mariano. La mora en el derecho civil y comercial. Su estructura y sus alcances. Buenos Aires: Abeledo-Perrot, 1979.

GALLO, Paolo. "Arricchimento senza causa. Artt. 2041-2042", en Il Codice Civile. Commentario. Fondata da Piero Schlesinger, diretto da Francesco D. Busnelli. Milano: Giuffrè, 2003.

LEVI, Giulio. Il pagamento dell'indebito. Milano: Giuffrè, 1989.

MAZZONI, Cosimo Marco. "Frutti civili e interessi di capitale". Quaderni di Giurisprudenza Comérciale 75. Milano: Giuffrè, 1985.

MELLO, Marcos Bernardes de. Teoria do fato jurídico. 2. ${ }^{a}$ ediçåo. Såo Paulo: Saraiva, 1986.

OSTERLING PARODI, Felipe (con la colaboración de Carlos CÁRDENAS QUIRÓS). Las obligaciones. Biblioteca Para leer el Código Civil. Volumen VI. Lima: Fondo Editorial de la Pontificia Universidad Católica del Perú, 1988.

ROSSELLO, Carlo. "L'errore nel contratto. Artt. 1427-1433", en Il Codice Civile. Commentario. Milano: Giuffrè, 2004.

RUBIO CORREA, Marcial. El sistema jurídico. Introducción al derecho. Lima: Fondo Editorial de la Pontificia Universidad Católica del Perú, 2004.

SÁNCHEZ CALERO, Francisco Javier. "Las obligaciones genéricas". Revista de Derecho Privado. Madrid, 1980.

TRIMARCHI, Pietro. Istituzioni di diritto privato. Quindicesima edizione. Milano: Giuffrè, 2003.

TUR FAUNDEZ, María Nélida. El derecho de reembolso. Valencia: Editorial General de Derecho, 1996.

TURCO, Claudio. "L'adempimento del terzo. Art. 1180", en Il Codice Civile. Commentario. Diretto da Piero Schlesinger. Milano: Giuffrè, 2002.

VISINTINI, Giovanna. Responsabilidad contractual y extracontractual. Lima: Ara, 2002.

VISINTINI, Giovanna. "Inadempimento e mora del debitore. Artt. 12181222", en Il Codice Civile. Commentario. Diretto da Piero Schlesinger. Milano: Giuffrè, 1987. 